\title{
Clitoral Gland
}

National Cancer Institute

\section{Source}

National Cancer Institute. Clitoral Gland. NCI Thesaurus. Code C77617.

A female reproductive gland located on the side of the clitoris. 